\title{
Plant Biomass from Grasses: An Underutilized Feedstock for Microbial Production of Chemicals and Biopolymers
}

\section{Thomas P. West*}

Department of Biology and Microbiology, South Dakota State University Brookings, SD 57007, USA

\begin{abstract}
Plant biomass from grasses is an underutilized feedstock for the microbial production of chemicals and biopolymers. Hydrolysates of this type of plant biomass provide sufficient levels of glucose or xylose to support specialty chemical and biopolymer production. Considering the availability of these grasses worldwide, additional studies are needed to determine whether the production of industrially important chemicals and biopolymers from grasses using microbial bioconversion is feasible.
\end{abstract}

Keywords: Grass; Specialty chemicals; Biopolymers; Microbial bioconversion

If biobased-related products are to replace petroleum-related products, new methodologies, where various types of lignocellulosic biomass undergo bioprocessing to commercially important products, must be devised [1]. A relatively low value lignocellulosic biomass that could be utilized to produce biobased-related coproducts is grass. Currently, many grasses are largely utilized for grazing by livestock or harvested as hay [2]. For example, many North American prairie grasses produce a high yield with minimal fertilizer input and they contain a very high fiber content indicating a high level of cellulose and hemicellulose [2]. A high concentration of cellulose and hemicellulose can be released by treatment of grass biomass [3]. Subsequent cellulase and xylanase treatment of the treated biomass has been found to release glucose and xylose $[3,4]$. The fermentable glucose released from the hydrolyzed cellulose following enzymatic treatment of the biomass can be converted to chemicals such as citric acid, fumaric acid, gluconic acid, itaconic acid, lactic acid, malic acid, oxalic acid, propionic acid and succinic acid as well as biopolymers such as polysaccharide gums by microbial strains. Citric acid, gluconic acid, itaconic acid, malic acid and oxalic acid can be produced from glucose by species of the fungus Aspergillus [5,6]. The bacterium Propionibacterium acidipropionici has been shown to produce propionic acid from glucose while species of Lactobacillus produce lactic acid from glucose [5]. A number of anaerobic bacteria are capable of producing succinic acid from glucose [5]. Fumaric acid can be synthesized from glucose by a fungus and a genetically engineered bacterial species [5]. The fermentable xylose released from the hydrolyzed biomass can be converted to xylitol by yeast species [7]. Polysaccharide gums, such as pullulan or curdlan, can be synthesized from glucose by microorganisms $[8,9]$ The literature examining microbial specialty chemical or biopolymer production from grass hydrolysates is extremely limited. It has been shown that hydrolysates of plant biomass can support fungal citric acid production by Aspergillus niger or fumaric acid production by Rhizopus oryzae using solid-state fermentation $[10,11]$. Also, a xylanase hydrolysate of the grass big bluestem supported the production of xylitol by Candida species [7]. The opportunity exists to use grass as a plant biomass feedstock for the production of chemicals and biopolymers to decrease reliance on petroleum- based feed stocks for their production. To exploit this opportunity, the feasibility of using microbial bioconversion to produce chemicals and polysaccharide gums from the fermentable sugars present in hydrolysates of various grass species will need to be more intensively investigated.

\section{References}

1. Zhang YH (2008) Reviving the carbohydrate economy via multi-product lignocellulose biorefineries. J Ind Microbiol Biotechnol 35: 367-375.

2. Gonzalez-Hernandez JL, Sarath G, Stein JM, Owens V, Gedye K, et al. (2009) A multiple species approach to biomass production from native herbaceous perennial feedstocks. In Vitro Cell Devel Biol-Plant 45: 267-281.

3. Feltus FA, Vandenbrink (2012) Bioenergy grass feedstock: current options and prospects for trait improvement using emerging genetic, genomic, and systems biology toolkits. Biotechnol Biofuels 5: 80 .

4. Lee JM, Shi J, Richard A, Jameel H (2009) Autohydrolysis pretreatment of coastal bermuda grass for increased enzyme hydrolysis. Bioresour Technol 100: 6434- 6441

5. Straathof AJJ (2013) Transformation of biomass into commodity chemicals using enzymes or cells. Chem Rev 113: (in press). Doi: 10.1021/cr400309c

6. Mandal SK, Banerjee PC (2005) Submerged production of oxalic acid from glucose by immobilized Aspergillus niger. Process Biochem 40: 1605-1610.

7. West TP (2009) Xylitol production by Candida species grown on a grass hydrolysate. World J Microbiol Biotechnol 25: 913-916.

8. Cheng K-C, Demirci A, Catchmark JM (2011) Pullulan: biosynthesis, production and applications. Appl Microbiol Biochem 92: 29-44.

9. Zhan X-B, Lin C-C, Zhang H-T (2012) Recent advances in curdlan biosynthesis biotechnological production, and applications. Appl Microbiol Biotechnol 93: 525-553.

10. Xie G and West TP (2006) Citric acid production by Aspergillus niger on wet corn distillers grains. Lett Appl Microbiol 43: 269-273.

11. West TP (2008) Fumaric acid production by Rhizopus oryzae on corn distillers' grains with solubles. Res J Microbiol 3: 35-40.

*Corresponding author: Thomas P. West, Department of Biology and Microbiology, South Dakota State University, Box 2104A, Brookings, SD 57007 USA Tel: 605-688-5469; Fax: 605-688-6677, E-mail: Thomas.West@sdstate.edu

Received October 28, 2013; Accepted October 30, 2013; Published November 04, 2013

Citation: West TP (2013) Plant Biomass from Grasses: An Underutilized Feedstock for Microbial Production of Chemicals and Biopolymers. J Microb Biochem Technol 5: e115. doi:10.4172/1948-5948.1000e115

Copyright: (c) 2013 West TP. This is an open-access article distributed under the terms of the Creative Commons Attribution License, which permits unrestricted use, distribution, and reproduction in any medium, provided the original author and source are credited 